\title{
The Impact Of Product Innovation And Market Orientation On The Competitive Advantage of Souvenirs In Padang
}

\author{
Vicky Brama Kumbara, M. Afuan \\ Universitas Putra Indonesia YPTK Padang, Indonesia \\ E-mail : vickybrama@upiyptk.ac.id
}

\begin{abstract}
This study aims to analyze the influence of the dimensions of product innovation (product feature innovation, product packaging innovation, and product uniqueness innovation) and market orientation towards competitive advantage of bengkuang processed products in Padang. The population in this study are UMKM in Padang who sell bengkuang. There were 100 respondents taken by using purposive sampling technique. The data was analyzed by using path analysis through SPSS software.
\end{abstract}

Keyword: Product Innovation, Market Orientation and Competitive advantage

\section{Introduction}

Current competitive environment in the business sector is quite tight and complex. Every company is required to always understand and comprehend what is happening in the market and what is the desire of consumers, and changes that exist to be able to compete with the competitors. The changes are related to how companies innovate to answer what consumers want, competition with other competitors, and changes in the market. The company hopes to be able to create products that are completely new or different from the previous ones or make products that are improvements from existing products by innovating [1]. Consumers are not only limited to looking at the value or function of a product that is needed, consumers also pay attention to whether the product chosen has added value or advantages compared to other similar products in consuming a product. The development of a successful innovation will be the right strategy to maintain the product's position in the market, because most of the competing products appear static from year to year.

With the increasingly intense competition, companies must understand what and how to manage their various resources. An important key to winning competition lies in the company's ability to create competitive advantage. state that competitive advantage can be achieved if the company is able to provide more value to customers than what is given by its competitors. Competitive advantage can come from various company activities such as in designing, producing, marketing, delivering, and supporting its products [2]. Each of these activities must be directed to support the relative cost position of the company and create a basis for creating differentiation. In order to win in a competition, the current marketing of the product is not only based on the quality of the product, but also depends on the strategy adopted by the company. Related to that there are two strategies that are generally used by companies, namely market orientation and innovation [3].

Innovation can also be used as one of the strategies in achieving competitive advantage. The main objective of product innovation is to meet market demand so that product innovation is one that can be used as a competitive advantage for companies [4]. Customers generally want innovative products according to their wishes. For companies, its success in product innovation means the company is one step ahead compared to its competitors. This requires the intelligence of the company in recognizing the tastes of its customers so that the innovation it does ultimately is in accordance with the wishes of its customers. Thus product innovation must be truly planned and carried out carefully. Innovation is also one of the important variables in determining performance. Innovation is becoming increasingly important 
as a means of survival, not just growth in the face of environmental uncertainty and increasing business competition conditions. Companies with high innovation ability will be more successful in responding to the environment and developing new capabilities that lead to competitive advantage and superior performance.

Market orientation is a corporate culture that can lead to increased marketing performance. Market orientation has three components, namely customer orientation, competitor orientation, interfunctional coordination. Customer orientation is a sufficient understanding of current strengths and weaknesses as well as the capabilities and long-term strategies of existing competitors and potential competitors. The relationship between market orientation and company competitive advantage will vary in the situation and will accelerate market growth. Companies in marketing products must be market oriented because market demand can be achieved to the maximum.

The choice of bengkuang processed business as the object to be examined in this study is because the bengkuang processed product business is an industrial sector that is a mainstay for the local and export markets, especially after the increase in fuel oil (BBM) and basic electricity tariff (TDL). The still large market condition is a big opportunity for yam processed products in Padang City to further develop market penetration both for export and domestic needs. The city of Padang was chosen because this area is a business center for processed bengkuang products in Sumatra, and the object of this research is a small scale yam processed products, with the reason that industries that are on a small scale are still quite limited in applying technology.

The high level of competition is not only felt by large companies but also mediumsized companies in Indonesia like bengkuang processed products industry in Padang and Solok, West Sumatra. Changes that occur in the bengkuang processed products industry include an increase in the level of industrial competition, the price of raw materials, and a decrease in exports abroad. The level of competition that is increasingly fierce in the bengkuang processed products industry occurs due to reduced domestic market share, thus demanding companies in this industry to implement strategies that are relevant to company conditions and the changing environment. The company must keep trying to maintain its survival. The company's progress in the bengkuang processed industry is entirely dependent on the company's ability to create and grow competitiveness that can adjust quickly to changes. The following table will present an overview of the condition of the bengkuang processed products industry in Padang.

Table 1. Ministry of Industry and Trade of West Sumatra, 2017[5]

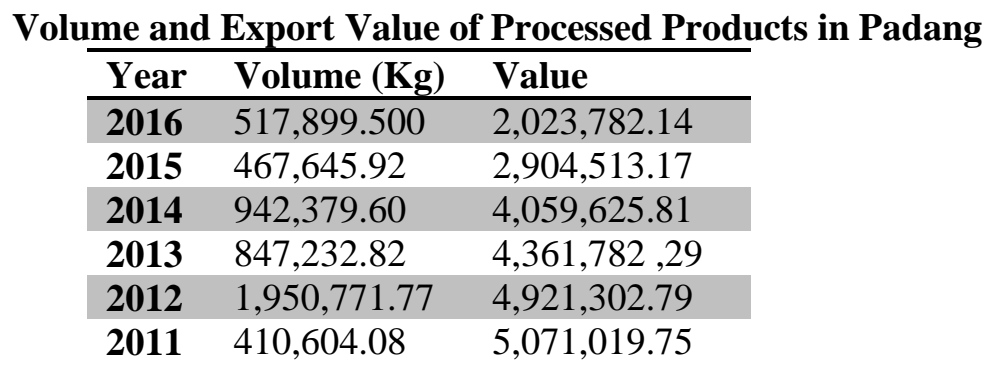

Based on Table 1.1 above, it appears that the volume and export value of bengkuang processed products in Padang are experiencing unstable conditions. In 2014, the volume of bengkuang processed products reached $942,379.60 \mathrm{~kg}$ and decreased in 2015 to 467,645.92 kg. But in 2016 the volume increased again. According to a source from the Department of Industry and Trade of Padang, this unstable condition was affected by the economic crisis, rising fertilizer prices, and rising electricity tariffs. Even so, the existence of bengkuang processed products in Padang must still be maintained, remembering that bengkuang is an icon of Padang. 
Companies engaged in bengkuang processed products must be encouraged so that they have a strong competitive advantage.

\section{Method Research}

The method used in this study is a quantitative method using survey methods. This research was conducted to determine the effect of the dimensions of product innovation (product feature innovation, product packaging innovation, and product uniqueness innovation) on the competitive advantage of bengkuang processed products in Padang where market orientation used as a mediating variable. The theoretical framework can be seen in Figure 1. This research is an explanatory research that is research that tests existing hypotheses. Data collection techniques with a survey by using a self administered survey in which each questionnaire is filled directly by the respondent.

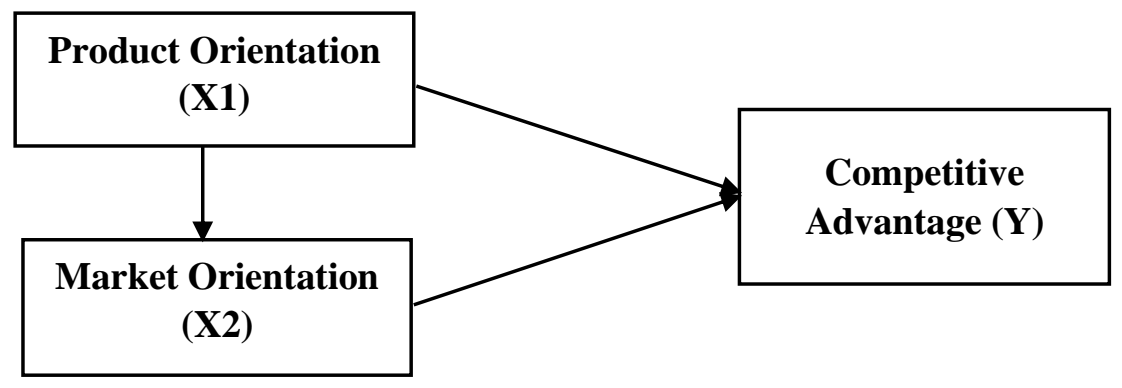

Figure 1

Theoritical Framework

Product innovation refers to the development of the product, the improvement of performance, and / or the new features to an existing product. It measures by using several indicators, such as; (1) the ability of brands to renew new products with new features, and (2) provide new alternatives to customers that differentiate them from competitors (Hanaysha, 2016), (3) the power of creativity, technical innovation, design changes, changes in distribution systems, and payment administration systems (Zainul, 2016). Product feature innovation is related to how consumers use information about product attributes in evaluating products. Product packaging innovation related to the design of packaging that describes the product or brand image. Then, the product uniqueness innovation is related to product differentiation for the development and enhancement of user's personal and social identity (Seng, 2016).

Product competitiveness is a product's ability to gain excellence in the market that is achieved by increasing the value of the product. This is evidenced by the expansion of market share and increasing prices of these products in the market which have a very positive impact on the position of the product profit margin. It measures by using several indicators, such as; (1) competitive price, (2) product quality, (3) competitive advantage (Hana, 2013).

All questionnaires are distributed to selected respondents who meet the criteria. Data analysis using path analysis through SPSS software.

\section{Results and Discussion}

This section discussed the findings from the survey questionnaires that have been distributed to the respondents Padang. From 100 questionnaires distributed to various respondents, the demographical results were shown in Figure 1. 
1. Path Analysis

To test the hypothesis in this study, path analysis divided into 2 sub-structures.

a. First Substructure

The first sub-structure is carried out to analyze the effect of the Product Innovation variable $\left(\mathrm{X}_{1}\right)$ on the Market Orientation variable $\left(\mathrm{X}_{2}\right)$. Where the results of the analysis are seen in Table 10 Based on the path analysis results shown in Table 10, it is showed that the exogenous variable influences the endogenous variable. The path coefficient $\mathrm{X}_{1}$ $\left(\mathrm{P}_{\mathrm{X} 2 \mathrm{X} 1}\right)$ is 0.351 . Thus, it can proceed to the analysis of the second sub-structure.

Table 2. Coefficient of Product Innovation Path to Market Orientation

\begin{tabular}{clccc}
\hline No & \multicolumn{1}{c}{ Variable } & Path coefficient & t count & Sig. \\
\hline $\mathbf{1}$ & Product Innovation & 0.351 & 4.837 & 0.000 \\
& R Square $=0.193$ & & & \\
\hline
\end{tabular}

By recognizing the value of $R$ Square in Table 10. It can be calculated coefficient values of other variables $\left(\mathrm{P}_{\mathrm{X} 2 \mathrm{e}}\right)$ with the formula:

$$
\begin{aligned}
& P_{X 3 e}=\sqrt{1-R^{2}} \\
& P_{X 3 e}=\sqrt{1-0.193} \\
& P_{X 3 e}=0.963
\end{aligned}
$$

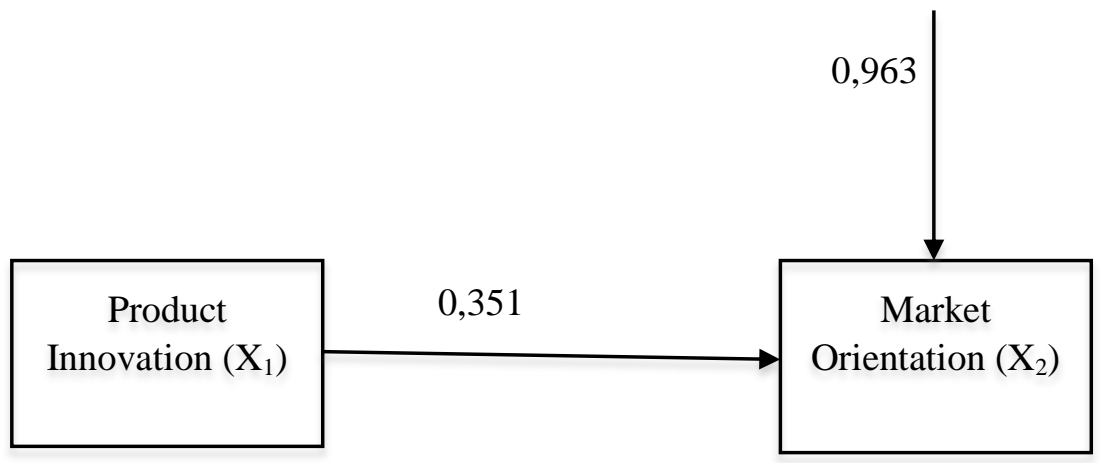

Thus, it can be presented diagrams path analysis to influence product innovations to market orientation variable.

Figure 2. First Sub-Structure Path Diagram

\section{b. Second Substructure}

The second sub-structure is carried out to analyze the influence variables of product innovation(X1) and market orientation (X2) on competitive advantage (Y). Where the results of the analysis are seen in Table 11. 
Table 3. Coefficient of Product Innovation Path and Market Orientation on Competitive Advantages of Bengkuang Processed Products in Padang

\begin{tabular}{clccc}
\hline No & \multicolumn{1}{c}{ Variable } & Path coefficient & t count & Sig. \\
\hline $\mathbf{1}$ & Product Innovation & 0.018 & 0.372 & 0.711 \\
$\mathbf{2}$ & Market Orientation & 0.385 & 6.297 & 0.000 \\
& R Square $=0.348$ & & & \\
\hline
\end{tabular}

Based on the results of the path analysis shown in the Table, it is known that one exogenous variable has no significant effect on endogenous variables, namely product innovation. This can be seen from the value of Sig. which is greater than 0.05. Only market orientation variables affect competitive advantage. Therefore, it is necessary to do trimming by issuing variables that have no significant effect on the competitive advantage of bengkuang processed products. The results are trimming presented in Table 12 below:

Table 4. Path Coefficient Market Orientation on Competitive Advantage Bengkuang Processed Products

\begin{tabular}{ccccc}
\hline No & Variable & Path coefficient & t count & Sig. \\
\hline 1 & Market orientation & 0.395 & 7.222 & 0.000 \\
& R Square $=0.589$ & & & \\
\hline
\end{tabular}

Based on the data shown in Table 12, note the path coefficient $\mathrm{X}_{3}\left(\mathrm{P}_{\mathrm{YX} 3}\right)$ is 0.395 . It can be concluded that the exogenous variable influences on the endogenous variable.By knowing the value of $R$ Square in Table 12, it can be calculated the value of the path coefficient of other variables $\left(\mathrm{P}_{\mathrm{Ye}}\right)$ with the formula:

$$
\begin{aligned}
& P_{Y e}=\sqrt{1-R^{2}} \\
& P_{Y e}=\sqrt{1-0.589} \\
& P_{Y e}=0.653
\end{aligned}
$$

Thus, it can be presented path analysis diagram for the influence of market orientation variables on competitive advantage of bengkuang processed products.

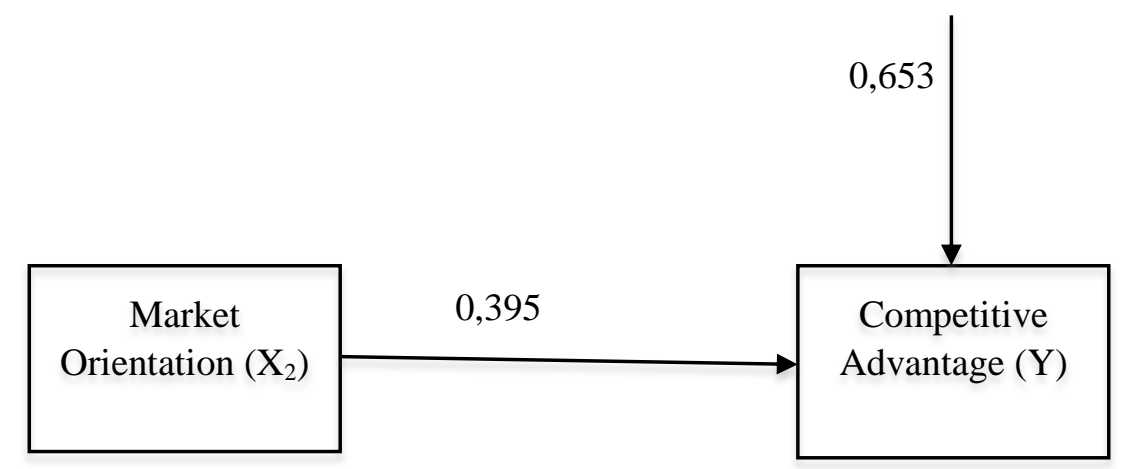

Figure 3. Second Sub-Structure Path Diagram 
From the analysis above can be obtained a new path structure between exogenous variables and endogenous variables as follows:

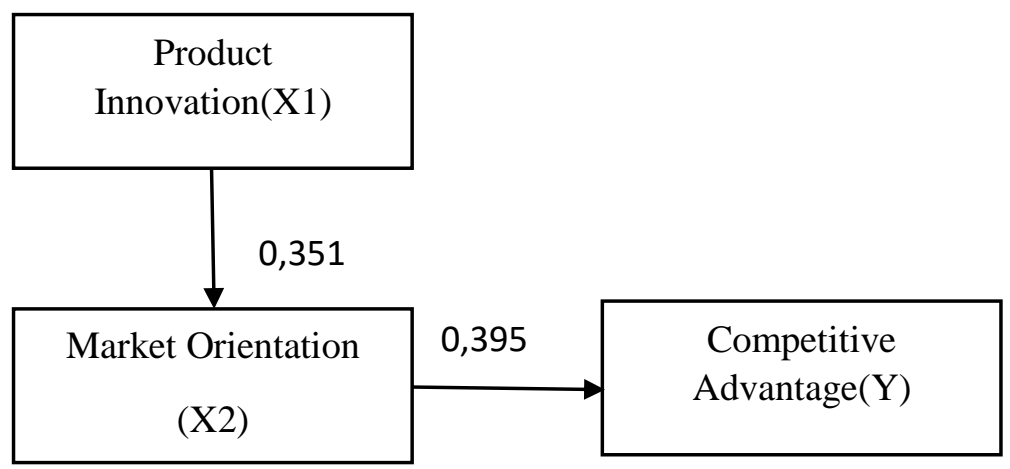

Figure 4. Final Structure of Relationships and Effects of Exogenous Variables on Endogenous Variables

a) The influence of product innovation on market orientation bengkuang processed product in Padang

Based on the results of the first hypothesis test it is known that product innovation has no significant influence on the market orientation of bengkuang processed products in Padang. Where the level is significantly greater than alpha $(0.711>0.05)$, it means that product innovation has no significant influence on the market orientation of bengkuang processed products in Padang. These results underline that the innovation of bengkuang processed products is not based on the market orientation. The results of this study are in line with research according to Mavondo et al (2005) he found that innovation does not have a significant influence on marketing performance. But the results of the study were stated not in line with research conducted by Gendut Sukarno (2009) that there was a positive and significant influence between product innovation on marketing performance. Product innovation is one of the most important factors in the process of improving the marketing performance of a product. Innovation is becoming increasingly important as a means of survival, not just growth in the face of environmental uncertainty and increasing business competition conditions. If you want to improve marketing performance, you must innovate products that are continuously adjusted to the desires of customers and internal functions and need to pay attention to what has been and will be done by competitors. Innovation is needed in order to create opportunities to offer customers higher value products or services, in addition to being able to create new markets or serve effectively. Innovations carried out in a focused and simple manner.

\section{b) The influence of product innovation on competitive advantage of bengkuang processed products in Padang}

Based on the results of the second hypothesis test it is known that product innovation has a significant positive influence on the competitive advantage of bengkuang processed products in Padang. Where the significant level is smaller than alpha $(0.004<0.05)$, it means that product innovation has a significant positive influence on the competitive advantage of bengkuang processed products in Padang. These results underline that the innovation of bengkuang processed products is based on competitive advantage. The results of this study are in line with research by Ayu Ningrum and Pangestuti (2018)[6] that there is a positive and significant influence between product innovation on the competitive advantage of bengkuang processed products in Padang. The innovation process is very important, because this will have an impact on competitive advantage. This opinion is also supported by the results of research conducted by Sandvik (2003)[7] which states that the more innovative a product is the value given to 
consumers will be higher and the level of differentiation offered will also be higher. Therefore, the greater the capacity of organizational innovation the greater the competitive advantage.

\section{c) The influence of market orientation on competitive advantage of bengkuang processed products in Padang}

Based on the results of the third hypothesis test, it is known that market orientation has a significant positive influence on the competitive advantage of bengkuang processed products in Padang. Where the significant level is smaller than alpha $(0,000<0.05)$, it means that market orientation has a significant positive influence on the competitive advantage of bengkuang processed products in Padang. These results underline that the orientation of bengkuang processed markets is based on competitive advantage. The results of this study are in line with research by Jayaningrum and Sanawiri (2018)[9] that there is a positive and significant influence between product innovation on the competitive advantage of bengkuang processed products in Padang. This condition shows that in order to have a competitive advantage, business owners of bengkuang processed products need to find as much market information as possible to find out what things are needed by consumers and what the market needs today. Consumer desires usually always change to follow the trends that become market tastes. It also needs to dig up information about the strategies carried out by competitors in order to predict and anticipate conditions that might occur in the market. By having a lot of information about market conditions, customer needs and strategies carried out by competitors, business owners can plan a strategy that is right on target so that it will automatically have a higher competitive advantage.

\section{The influence of product innovation and market orientation together on the competitive advantage of yam processed products in Padang.}

Based on the results of the fourth hypothesis test, it is known that product innovation and market orientation have a significant positive influence on the competitive advantage of bengkuang processed products in Padang. Where the significant level is smaller than alpha $(0,000<0.05)$, it means that product innovation and market orientation have a significant positive influence on the competitive advantage of bengkuang processed products in Padang. These results underline that product innovation and market orientation of bengkuang processed products are based on competitive advantage. The results of this study are in line with research by Jayaningrum and Sanawiri (2018)[10] that there is a positive and significant influence between product innovation and market orientation on the competitive advantage of bengkuang processed products in Padang. This illustrates that a good market orientation effort and diverse product innovations will also create high marketing performance. If there is a decrease in one of these factors will directly affect competitive advantage. The results showed that market orientation and product innovation are factors that can affect the achievement of competitive advantage in yam processed products.

Competitive advantage will be achieved through market orientation. The company will obtain actual, accurate and action-oriented market information. Innovation will be able to drive the market and improve marketing performance. By innovating the company will be more successful in responding to the environment and developing new capabilities where this can produce competitive advantages. So that innovation becomes increasingly important as one of the tools for survival, not only growth but also in competition. to get superior value, the company must really understand what the customer needs and wants are, as well as what innovations or changes must be made, so that consumers prefer products that are created over competing products, if the business owner is able to innovate the product and is able directing its products in accordance with the desires and needs of consumers and preferred by consumers, consumers will automatically choose the product and will have an impact on increasing sales volume which has an impact on the competitive advantage of these products. 


\section{Conclusions}

Based on the results of the analysis and hypothesis testing in this study, it can be concluded as follows:

1. There is a negative and insignificant influence between product innovation on the market orientation of bengkuang processed products in Padang. With the level of significant greater than alpha $(0.711>0.05)$.

2. There is a positive and significant influence between product innovation on the competitive advantage of bengkuang processed products in Padang. With the level of significant smaller than alpha $(0.004<0.05)$.

3. There is a positive and significant influence between market orientation and a significant positive effect on the competitive advantage of bengkuang processed products in Padang. With the level of significantly smaller than alpha $(0,000<0.05)$.

4. There is a positive and significant influence between product innovation and market orientation has a significant positive effect on the competitive advantage of bengkuang processed products in Padang. With the level of significant smaller than alpha $(0,000<0.05)$.

\section{Reference}

[1] Ahmad, Nawaz., et al., (2012). Effect of Product Packaging in Consumer Buying Decision, Journal of Business Strategies, 6(2) pp. 1-10.

[2] Augusto, M., \& Coelho, F. (2009). Market orientation and new-to-the-world products: exploring the moderating effects of innovativeness, competitive strength, and environmental forces. Industrial Marketing Management Journal, 94-108.

[3] Ahmad, R. A. (2013). Study on Brand Competitiveness and Customer Purchase Intention, Proceeding Entrepreneurship Vision 2020: Innovation, Development Sustainability, and Economic Growth, pp. 109-115.

[4] Baker, W. E., \& Sinkula, J. M. (2009). The synergetic effect of market orientation and learning orientation on organizational performance. Journal of the Academy of Marketing Science, 27(4), pp. 411-427.

[5] Camisón, C., \& López, A. V. (2011). Non-technical innovation: organizational memory and learning capabilities as antecedent factors with effects on sustained competitive advantage. Industrial Marketing Management, 40, pp. 1294-1304.

[6] Garcia, R., Calantone, R. (2002): A critical look at technological innovation typology and innovativeness terminology: a literature review, Journal of Product Innovation Management, 19: 110-132.

[7] Gogoi, B. (2013), Study of antecedents of purchase intention and its effect on brand loyalty of private label brand of apparel, International Journal of Sales \& Marketing, 3( 2), pp. 73-86

[8] Hadi, R. K. (2013). Pengaruh Keunggulan Produk Terhadap Minat Beli Konsumen Pada Produk Rangka Atap Baja Ringan Taso, Jurnal Sains Pemasaran Indonesia, XII(3), pp. 346-356.

[9] Hair, Jr., R.E. Anderson, R.L. Tatham, \& W.C. Black (2013), Multivariate Data Analysis A Global Perspective, 7th edition, Upper Saddle River, New jersey: Pearson Education.Inc.

[10] Hana, Urbancova. (2013). Competitive Advantage Achievement through Innovation and Knowledge, Journal of Competitiveness, 5(1), pp. 82-96. 